\title{
Thoracic disc herniation: case series and surgical approach protocol
}

\author{
Herniação discal torácica: série de casos e protocolo para \\ abordagem cirúrgica
}

\author{
Herniación de disco torácico: \\ serie de casos y protocolo de enfoque quirúrgico
}

\author{
Felipe Gargioni Barreto ${ }^{1}$, Enrico Affonso Barletta ${ }^{2}$, Telmo Augusto \\ Barba Belsuzarri ${ }^{3}$, Daniel de Araújo Paz ${ }^{4}$, Fabio Veiga de Castro \\ Sparapani ${ }^{5}$, Sergio Cavalheiro ${ }^{6}$, Thiago Salati ${ }^{7}$, Vinicius de Meldau \\ Benites $^{8}$, Eduardo Augusto Iunes ${ }^{9}$, Franz Jooji Onishi ${ }^{10}$
}

1.MD, Universidade Federal de São Paulo, Medical School, Neurosurgery Department. ORCID: https://orcid.org/0000-0003-3815-0963

2.Medical Student, Pontifical Catholic University of Campinas, Medical School, Medical Student. ORCID: https://orcid.org/0000-0002-1457-430X

3.MD, Pontifical Catholic University of Campinas, Medical School, Neurosurgery Department. Post Graduation Program. ORCID: https://orcid.org/0000-0001-6173-3193

4.MD, Universidade Federal de São Paulo, Medical School, Neurosurgery Department. ORCID: https://orcid.org/0000-0003-2683-986X

5.MD, PhD, Universidade Federal de São Paulo, Medical School, Neurosurgery Department. ORCID: https://orcid.org/0000-0003-4164-6548

6.MD, PhD, Universidade Federal de São Paulo, Medical School, Neurosurgery Department. ORCID: https://orcid.org/0000-0002-9750-0508

7.MD, Universidade Federal de São Paulo, Medical School, Neurosurgery Department. ORCID: https://orcid.org/0000-0002-5528-0164

8.MD, Universidade Federal de São Paulo, Medical School, Neurosurgery Department. ORCID: https://orcid.org/0000-0003-1693-9357

9.MD, Universidade Federal de São Paulo, Medical School, Neurosurgery Department. ORCID: https://orcid.org/0000-000239107222

10.MD MSc, Universidade Federal de São Paulo, Medical School, Neurosurgery Department. ORCID: https://orcid.org/0000-0002-5641-5104

\section{Resumo}

Objetivo. Descrever o desfecho cirúrgico da série de 11 casos submetidos a tratamento cirúrgico baseado no protocolo desenvolvido na nossa instituição para tratamento cirúrgico a hérnias de disco torácicas. Método. Os pacientes foram classificados quanto ao risco cirúrgico. Grupo A (alto risco cirúrgico) ou B (baixo risco cirúrgico); após, eram classificados quanto as características da hérnia: presença de calcificação, posição da hérnia (central ou lateral). A abordagem cirúrgica era definida conforme essas características. Grupo A.1) Hérnia central e calcificada em paciente de alto risco - Acesso toracoscópico; A2) Hérnia lateral não calcificada em paciente de alto risco - acesso póstero-lateral; A.3) Hérnia calcificada lateral - acesso póstero-lateral/ B.1) Hérnia central ou centro-lateral calcificada em pacientes de baixo riscotoracotomia ou toracoscopia. B.2) Hérnia lateral não calcificada em pacientes de baixo risco acesso póstero-lateral. Resultados. 11 pacientes foram submetidos a tratamento cirúrgico de hérnia de disco torácica baseado nesse protocolo ( 6 masculinos). 3 pacientes eram Frankel $C$

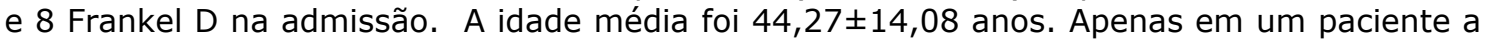
hérnia não era calcificada, 3 pacientes apresentaram hérnias laterais e 8 hérnias centrais. 0 tempo médio entre o início dos sintomas e a cirurgia foi de $9 \pm 10,81$ meses. 8 pacientes apresentaram melhora neurológica após a cirurgia. 3 pacientes (27\%) não apresentaram melhora. 2 pacientes tiveram ressecção parcial, um foi reoperado. Conclusões. Esse protocolo pode ser utilizado para planejamento pré-operatório das hérnias de disco torácicas principalmente levando em consideração as características do disco herniado.

Unitermos. Intervertebral; disco; deslocamento; torácico; tratamento e manejo 


\begin{abstract}
Objective. Describe the surgical outcome of a case series of 11 cases submitted to surgical treatment based on a protocol developed to suggest the best approach to treat thoracic disc displacement. Method. Patients were classified based on surgical risk: Group A (high surgical risk) or B (low surgical risk); thereafter, subgroups were defined based on herniation features: calcification, position (central or lateral). The surgical approach was used according to these two characteristics: A.1) Central Calcified displacement - Thoracoscopic approach; A.2) Lateral soft herniation - posterolateral approach; A.3) Lateral calcified displacement posterolateral approach; B.1) Central displacement or calcified centro-lateral displacement thoracotomy or thoracoscopic approach; B.2) Soft lateral herniation - posterolateral approach. Results. 11 patients have been treated with this protocol (6 males). Three patients were Frankel $C$ and eight Frankel D on admission. The average age was $44.27 \pm 14.08$ years. Just one patient had non-calcified displacement, 3 patients had lateral displacement and 8 central displacements. The average time from symptoms to surgery was $9 \pm 10.81$ months. 8 patients had improved after surgery. 3 patients $(27 \%)$ presented no improvement after surgery. No new neurological deficit was observed. No clinical complications occurred, although one patient had partial displacement removed and one patient needed additional surgery to remove residual displacement. Conclusions. This protocol can be used to plan the approach in thoracic disc displacement especially based on anatomical features of the herniated disc.
\end{abstract}

Keywords. Intervertebral; disc; displacement; thoracic; treatment and management

\title{
Resumen
}

Objetivo. Describir el resultado quirúrgico de una serie de 11 casos sometidos a tratamiento quirúrgico según el protocolo desarrollado en nuestra institución para el tratamiento quirúrgico de hernias de disco torácico. Método. Los pacientes fueron clasificaron según el riesgo quirúrgico. Grupo A (alto riesgo quirúrgico) o B (bajo riesgo quirúrgico); luego, se clasificaron según las características de la hernia: presencia de calcificación, posición de la hernia (central - lateral). El abordaje quirúrgico se definió de acuerdo con estas características. Grupo A.1) Hernia central y calcificada en un paciente de alto riesgo: acceso toracoscópico; A2) Hernia lateral no calcificada: acceso posterolateral; A.3) Hernia calcificada lateral: acceso posterolateral / B.1) Hernia central o centrolateral calcificada en pacientes de bajo riesgo: toracotomía o toracoscopia. B.2) Hernia lateral no calcificada: acceso posterolateral. Resultados. 11 pacientes fueron sometidos a tratamiento quirúrgico para hernia de disco torácico según este protocolo (6 hombres). 3 pacientes fueron Frankel C y 8 Frankel D al ingreso. La edad promedio fue de $44.27 \pm 14.08$ años. Solamente en un paciente la hernia no estaba calcificada, 3 pacientes tenían hernias laterales y 8 hernias centrales. El tiempo promedio entre el inicio de los síntomas y la cirúgia fue de $9 \pm 10.81$ meses. 8 pacientes mostraron mejoría neurológica después de la cirugía. 3 pacientes (27\%) no mostraron mejoría. 2 pacientes tuvieron resección parcial, uno fue reoperado. Conclusiones. Este protocolo puede ser utilizado para la planificación preoperatoria de las hernias de disco torácico, principalmente teniendo en cuenta las características de la hernia de disco.

Palabras clave. Intervertebral; disco; desplazamiento; torácico; tratamiento y manejo

Research developed at Universidade Federal de São Paulo, Hospital São Paulo, São Paulo-SP, Brazil.

\section{INTRODUCTION}

The incidence of thoracic disc herniation is low, however incidental herniation has been observed in up to $10-20 \%$ of 
random Magnetic Resonance Images (MRI), but only $1 / 1.000 .000$ patients presented neurologic symptoms due to such lesions ${ }^{1,2}$. Surgical treatment is indicated to approximately $0.15-4 \%$ of all disc herniations ${ }^{3}$. Apart from a challenging approach owing to the chest wall anatomy and the potential complications during lung manipulation, around $60 \%$ of those lesions are calcified what turns the procedure into an encumbering resection.

Considering this challenging scenario, an appropriate surgical approach is necessary to improve outcomes and prevent complications. This unusual surgery requires the largest evidence possible and surgeon experience. Countless approaches were used to manage this condition.

In the 50s, laminectomy was used with poor results with up to $70 \%$ of neurologic damage 4 . The anterolateral (transthoracic, thoracoscopic, retropleural thoracotomy) and lateral (extracavitary, costotransversectomy, and parascapular) approaches need huge muscular dissection, ribs resection, diaphragm dislocation, and a postoperative chest drain. Thereafter, posterolateral approaches were introduced into literature around 1978, when Patterson and Arbit $^{5}$ described the transpedicular approach allowing soft and lateral disc herniation resection. In 1995, Stillermann et al. described the transfacetal approach ${ }^{6}$, allowing partial calcified and central disc herniation. This approach presented lower morbidity and higher feasibility to most spine surgeons.

The most relevant factors to choose the appropriate 
approach for the surgical management of a thoracic disc herniation are the herniation features and the patient clinical status. Another important consideration is that the anterior approaches are, usually, more morbid. Therefore, we decided to create an algorithm to improve clinical outcomes in patients with thoracic disc herniation. To validate this algorithm update of a previously published paper, which disclosed the first 5 cases operated within this protocol, is being presented in the present article to establish the safe use of this protocol in patients with thoracic disc herniation.

\section{METHOD}

In January 2010 a protocol was designed to suggest the best approach to a thoracic disc herniation, based on literature findings ${ }^{7}$. To update our series a new literature review was performed. We used PubMed and Scielo as our database. Keywords used were: ((Intervertebral disc displacement) AND (thoracic) AND (treatment OR management). Reviews and clinical studies published in English, between 1987 and 2019 were included. A total of 51 articles were found, after abstract and titles analyze we selected 21 articles - they were all used in the present article.

11 cases were treated in our institute according to this protocol. Patients presenting with neurological or sphincter deficit accompanied by myelopathy secondary to a thoracic disc herniation on CT scan and MRI were studied. Patients with isolated radiculopathy, chest pain, and the absence of myelopathy were excluded. The time until the diagnosis, the 
Frankel grade, the epidemiological data of the patients were studied.

Once it was a retrospective study of surgical cases without any intervention or experimental subjects, ethical approval was not required in our institute. However, all patients had provided informed consent for the publication of this article. All authors affirm that no data that could expose the identity or other confidential information regarding these patients are available in the present work.

This research received approval from the Universidade Federal de São Paulo research ethics committee (\#203/21).

\section{Protocol}

The surgical approach is indicated only for patients with myelopathy. They were classified according to Frankel scale, and the and immediate post-op computed tomography. Regarding the surgical risk, patients were divided into two groups: A - High surgical risk (ASA C or Higher): 1) central and calcified herniation - Thoracoscopy; 2) Lateral soft displacement - posterolateral approach (transpedicular or transfacetal); 3) Centro lateral displacement - calcified: thoracoscopy, partial calcified and lateral posterolateral approach is also feasible. B - Low surgical risk (ASA A and $B)$ : 1) central displacement or centro lateral calcified displacement - thoracotomy or thoracoscopy; 2) Lateral soft displacement - posterolateral approach. 
The proposed approaches are summarized in Table 1. Each one is indicated mainly according to the position and consistency of the herniated disc as seen in Figure 1.

Figure 1. Different approaches described to treat thoracic disc herniation. Posterior approaches in white and yellow. Anterior approaches in blue.

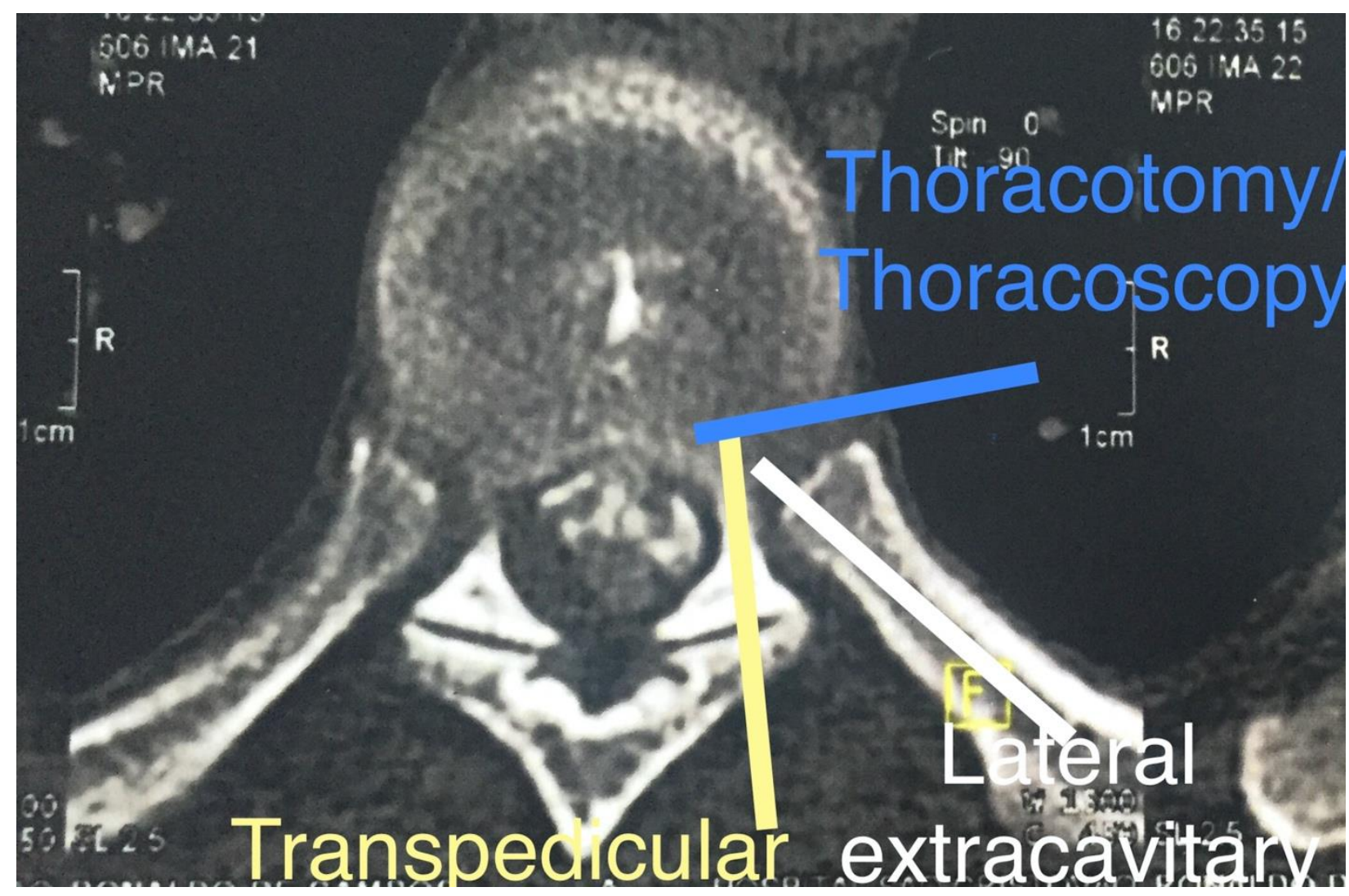

This protocol is based on previous reviews. The protocol was developed to avoid potential complications due to high morbidity approaches, especially in high surgical risk patients. Based on this, high-risk patients with lateral and soft herniation (Group A2) can be managed with a posterolateral approach. A3 group (central displacement in high-risk 
patients) can be managed by postero-lateral approach if the herniation is partially calcified and presents a lateral component, however, if the herniation is totally calcified and it's central, the thoracoscopy is the best choice.

Table 1. Proposed approaches protocol.

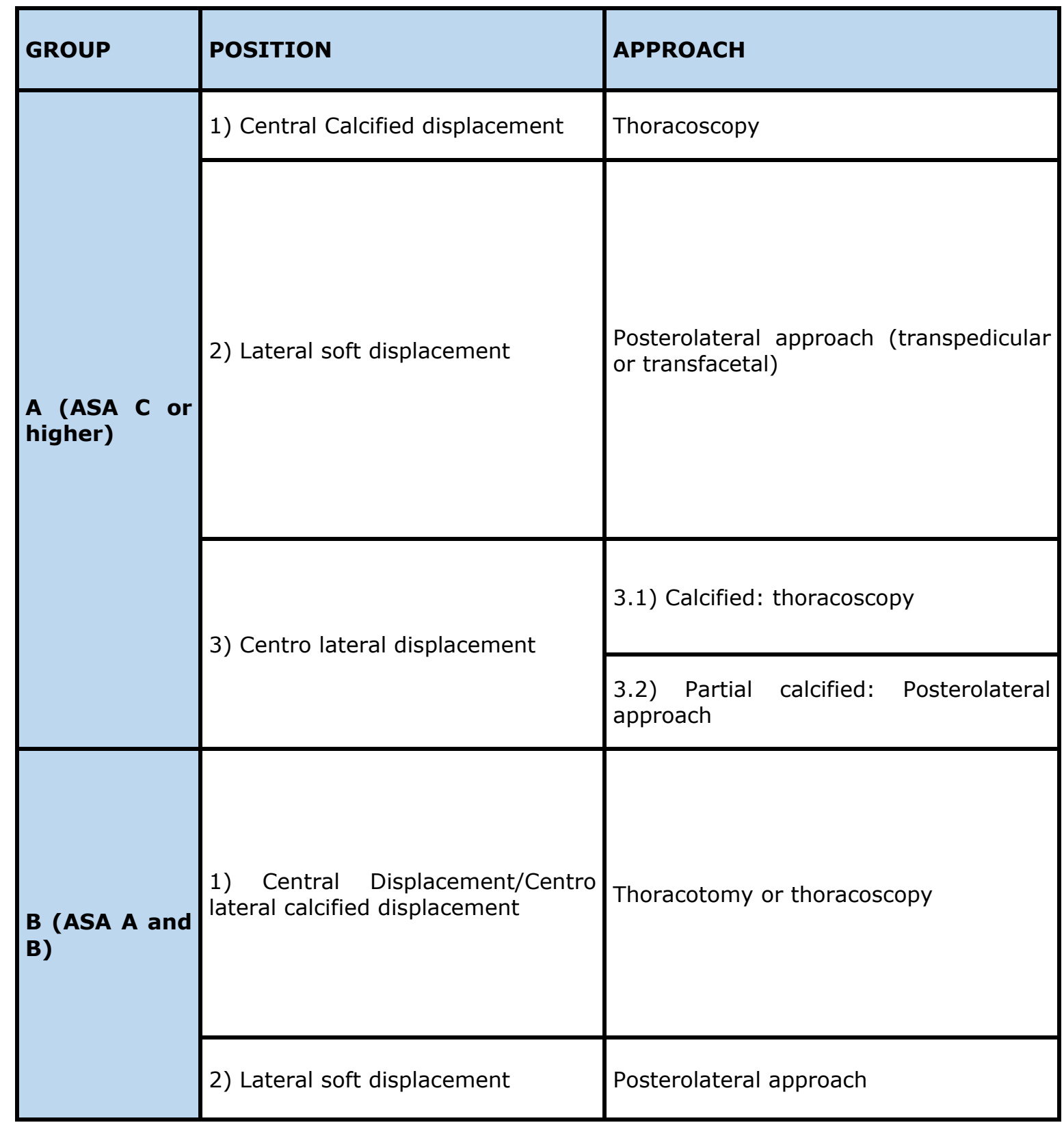




\section{RESULTS}

This is an original article, level IV of evidence. After the initial primary protocol, the other six patients were treated using the same principles. Therefore, we treated a total of 11 patients. Their average age was $44.27 \pm 14.08$ yo [30-74]. $6(54.6 \%)$ patients are male. Only one patient had a soft herniation. The average time from symptoms onset to surgery was $9 \pm 10.81$ months [2-36].

We had partial disc removal in 2 patients. One patient (patient 10) had partial removal of the calcified herniation. Nonetheless, she had an important neurological improvement and no reoperation was proposed. Other patient demanded an additional surgery to remove all the disc herniation because of the maintenance of the spinal cord compression.

Total resection was achieved in 9 patients. 3 patients (27\%) had no neurological improvement, however, no patient had new neurological deficits. 8 patients presented postoperative neurological improvement. Disc displacement was more prevalent on T10-11 level - 3 (27\%) patients, and T7-8, T9-10 and T11-12 were the second most prevalent with $2(18 \%)$ patients each. Herniation features and levels and Frankel scale results are presented in Table 2. For central calcified herniation, a thoracotomy approach was chosen. An illustrative case (case 11 ) is showed in Figure 2 . The cases studied in the present article are summarized in Table 3. 
Table 2. Herniation's features.

\begin{tabular}{lll}
\hline HERNIATION FEATURES & N (\%) \\
\hline Frankel grade C or D & $3(27)$ \\
\hline Calcified & $10(90)$ \\
\hline Median or paramedian & $10(90)$ \\
\hline Lateral & $1(9)$ \\
\hline Average time to surgery (in months) & 9 \\
\hline Total removal & $10(90)$ \\
\hline No neurological improvement & $3(27)$ \\
\hline & $\mathbf{T 7 - 8}$ & $2(18)$ \\
\cline { 2 - 3 } & $\mathbf{T 8 - 9}$ & $1(9)$ \\
\cline { 2 - 3 } Disease level & $\mathbf{T 9 - 1 0}$ & $2(18)$ \\
\cline { 2 - 3 } & $\mathbf{T 1 0 - 1 1}$ & $3(27)$ \\
\cline { 2 - 3 } & $\mathbf{T 1 1 - 1 2}$ & $2(18)$ \\
\cline { 2 - 3 } & $\mathbf{T 1 2 - L 1}$ & $1(9)$ \\
\hline
\end{tabular}

Figure 2. Patient 11: T7-T8 disc displacement, thoracotomy was proposed.

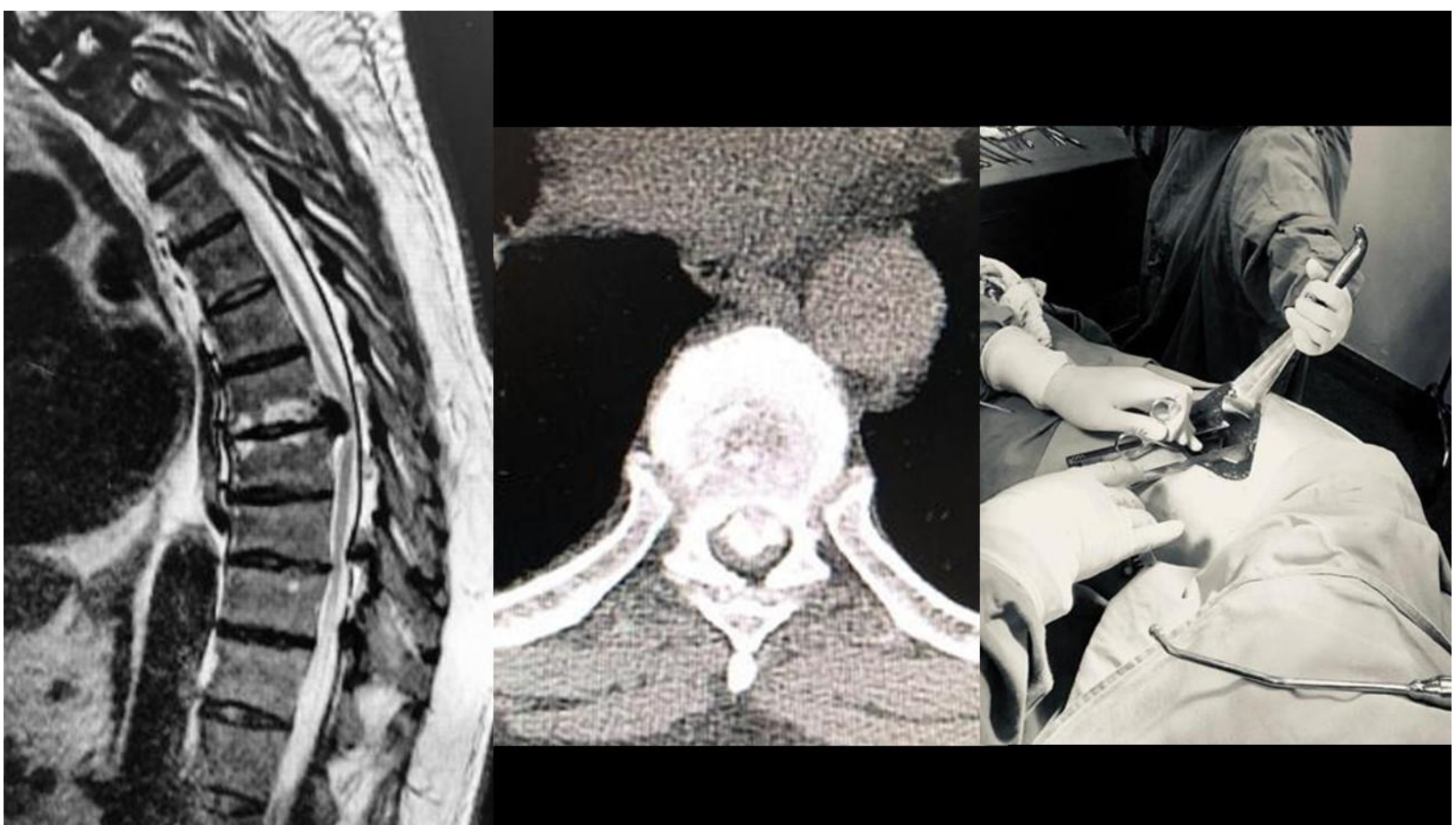


Table 3. Cases summary.

\begin{tabular}{|c|c|c|c|c|c|c|c|c|c|c|}
\hline Case & Age & Sex & \begin{tabular}{|l|} 
Frankel \\
Classification
\end{tabular} & $\begin{array}{l}\text { Time to } \\
\text { surgery } \\
\text { (Months) }\end{array}$ & Level & $\begin{array}{l}\text { Calcification } \\
\text { and } \\
\text { Displacement } \\
\text { Status }\end{array}$ & Group & Approach & Outcome & $\begin{array}{l}\text { Grade of } \\
\text { Removal }\end{array}$ \\
\hline \multirow[b]{2}{*}{1} & \multirow[b]{2}{*}{43} & \multirow[b]{2}{*}{ M } & \multirow[b]{2}{*}{ FD } & \multirow[b]{2}{*}{36} & \multirow{2}{*}{$\begin{array}{l}\text { T11- } \\
12\end{array}$} & PC & \multirow[b]{2}{*}{ A.3.2 } & \multirow[b]{2}{*}{$\mathrm{PL}$} & \multirow[b]{2}{*}{ G } & \multirow[b]{2}{*}{$\mathrm{T}$} \\
\hline & & & & & & $\mathrm{CL}$ & & & & \\
\hline \multirow{2}{*}{2} & \multirow{2}{*}{38} & \multirow{2}{*}{$\mathrm{F}$} & \multirow{2}{*}{ FC } & \multirow{2}{*}{6} & \multirow{2}{*}{$\begin{array}{l}\text { T10- } \\
11\end{array}$} & TC & \multirow{2}{*}{ B. 1} & \multirow{2}{*}{$\mathrm{Tt}$} & \multirow{2}{*}{ G } & \multirow{2}{*}{ T } \\
\hline & & & & & & C & & & & \\
\hline \multirow{2}{*}{3} & \multirow{2}{*}{30} & \multirow{2}{*}{$\mathrm{F}$} & \multirow{2}{*}{ FC } & \multirow{2}{*}{2} & \multirow{2}{*}{ T7-8 } & TC & \multirow{2}{*}{ B. 1} & \multirow{2}{*}{ Tcs } & \multirow{2}{*}{ B } & \multirow{2}{*}{$T^{*}$} \\
\hline & & & & & & C & & & & \\
\hline \multirow{2}{*}{4} & & & & & T12- & TC & & & & \\
\hline & ונה & MI & rD & 4 & L1 & c & 0.1 & Tा & 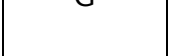 & 1 \\
\hline 5 & 58 & $\mathrm{~F}$ & FD & 6 & T11- & TC & $R_{1}$ & Tt & $R$ & $T$ \\
\hline 5 & 58 & $r$ & $\mathrm{FD}$ & 0 & 12 & c & D.1 & $\pi$ & $\mathrm{D}$ & 1 \\
\hline & & & & & T9- & TC & & & & \\
\hline 6 & 33 & $\mathrm{MI}$ & FD & 5 & 10 & C & B.1 & $\pi$ & $G$ & 1 \\
\hline & & & & & & TC & & & & \\
\hline 7 & 55 & M & FD & 24 & T8-T9 & C & B.1 & Tt & G & $\mathrm{T}$ \\
\hline 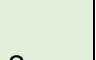 & & & & & T11- & NC & & & & $T$ \\
\hline 0 & 14 & $r$ & rD & 4 & T12 & $\mathrm{L}$ & AL & PL & 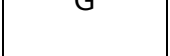 & 1 \\
\hline 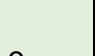 & 7 & 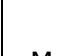 & חת & 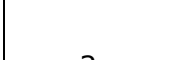 & T9- & TC & 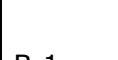 & $T_{t}$ & & \\
\hline$y$ & בכב & m & rD & 2 & T10 & C & D.1 & $\pi$ & 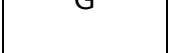 & 1 \\
\hline 10 & 2 & $\Gamma$ & - & 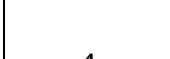 & T10- & TC & 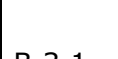 & $T_{-}$ & ( & D \\
\hline 10 & 32 & 1 & 10 & & & $\mathrm{CL}$ & & & & \\
\hline & & & & & & TC & & & & \\
\hline 11 & 54 & $\mathrm{M}$ & $F C$ & 6 & $17-8$ & C & B.1 & ICS & B & 1 \\
\hline$M-M$ & Iale $\mathrm{F}$ - & - Fem & e FC: FRANKEL & C FD: FRAN & VKEL D & & & & & \\
\hline $\mathrm{PC}-\mathrm{Pa}$ & artial C & Calcifie & d TC- Totally Cal & Icified NC - & Non-Calc & Icified C - Centra & I CL- Cer & ntro Lateral & & \\
\hline$P L-P$ & Postero & -Late & al Tt - Thoracoto & omy Tcs - T & horacosc & copy G - Good O & utcome & B - Bad Out & come & \\
\hline
\end{tabular}




\section{DISCUSSION}

Many different approaches have been proposed to thoracic disc displacement. Central and calcified discs are particularly challenging to spinal cord decompression. The most important goal is to minimize the manipulation of the spinal cord and decompress the neurological elements from the disc herniation. To avoid anterolateral transthoracic approach, some authors advocate in favor of posterolateral approach with some different techniques ${ }^{8-10}$.

\section{Posterior approaches}

Khoo et $a /^{9}$ described a case series of thirteen patients managed with lateral tubular approach for discectomy, decompression, and interbody cage fusion. Eleven patients had improved from their symptoms, two patients had no improvement.

Chi et $a l^{8}$ proposed a tubular paramedian approach and compared it with open transpedicular discectomy. Seven patients were submitted to tubular paramedian approach and four to open technique, the groups had similar outcomes on two years follow-up. In this series only lateral disc displacement were studied. For median disc displacement the authors preferred transthoracic approaches.

Regev et $a /^{10}$ reported twelve patients who underwent transforaminal tubular microscopic discectomy. All patients had improved, although median positioned and calcified discs were not included in this study, and just 2 patients had pre-operative Frankel $D$, all others were Frankel $E$. 
Daher et $a l^{11}$ reported thirteen patients, all managed by a posterior approach, six of them with central disc displacement and seven calcified, eight patients had myelopathy. Five patients had improved after surgery and no patients had neurological worsening after the surgeries. Fusion was made in eleven patients, and an interbody cage was used in one case.

Sivakumaran et $a 1^{12}$ reported 24 patients with a posterior approach. Thirteen were calcified or partially calcified, 7 were central. Twenty-one with myelopathy, 13 had improved and no post-op neurological deterioration was observed. One patient needed two operations to achieve total resection.

\section{Anterior approaches}

Anterior approaches had the advantage of less bone removal and then fewer fusion procedures needed. Direct visualization and less spinal cord manipulation are other advantages.

Oltulu et $a /^{13}$ compared anterior and posterior approaches in a series of 86 patients, 18 patients were submitted to a posterior approach and 68 to an anterior approach. Major complications occurred in $5.9 \%$ of anterior vs $33.3 \%$ in posterior approaches. Dural tear and neurological deterioration were major complications observed in posterior approaches, although the two patients with permanent neurological deterioration had a central and calcified disc herniation, what could be better managed from 
anterior approach. On these cases the morbidity from posterior approach, which is lower in general cases, is higher due to difficulty in visualized herniation and mobilization of herniation on calcified discs.

Nacar et $a{ }^{14}$ reported 33 patients approached by lateral minimally invasive thoracotomy, 25 trans pleural approach and last 8 retro pleural approaches. Twenty-three patients (69\%) had myelopathy. 21 patients had improved. Complications occurred in 6 patients.

Uribe et $a /^{15}$ reported 60 patients submitted to a miniopen lateral approach with retro pleural technique. 4 patients $(6.7 \%)$ presented major complications. One patient needed reoperation to remove residual disc displacement. One patient had pneumonia, one had a pneumothorax and one had a new deficit on the leg with posterior recovery.

Ayhan et al ${ }^{16}$ reported 27 patients with myelopathy submitted to transthoracic discectomy, 12 patients had improved, 2 patients had neurological deterioration. Instrumentation was used in 18 patients, 6 major complications occurred. One patient had plates screw loosening, one had a vertebral compression fracture, one had a hardware failure, one had tension pneumothorax, one had empyema and one deep venous thrombosis. All patients were submitted to thoracic drainage.

Moran et $a l^{17}$ reported 17 patients managed from anterior approach, all with myelopathy on clinical presentation. 13 had improved and no patient had neurological worsening. No fusion was used, one patient 
needed thoracic drain. Two had major complications: one died from pneumonia, one had pulmonary embolism.

Zhao et al ${ }^{18}$ reported 15 patients with myelopathy, 9 patients had improved, 6 patients had no improvement, no patient had neurological deterioration. Fusion was used in all patients, 2 patients developed major complications (pneumonia and cardiac event).

Arts et $a l^{19}$ compared anterior and posterior approach in 100 patients. Sixty-four patients had myelopathy. The route was chosen based on localization and calcification of the disc. Half of patients of anterior approach improved from myelopathy, $37 \%$ of posterior approach improved on Frankel scale. From long-term follow-up $72 \%$ of patients had good outcomes on thoracotomy group and $76 \%$ on posterior approach. Complication rate was higher on anterior approach.

Russo et a/20 performed a mini-thoracotomy without fusion to treat giant thoracic disc herniations in 7 consecutive patients. Average canal encroachment was $73.2 \%, 5$ discs were calcified, 3 had transdural components. Nurick grade was used to measure neurological deficits. The average initial Nurick was 3.5 (all patients had myelopathy on presentation) and all patients improved after surgery with an average Nurick grade scale of 1.28 on the last follow-up. One patient had post-operative dural fistula manages with lumbar drainage. Two patients had intercostal neuralgia.

In our series, all anterior approaches were trans-pleural and thoracic drain was used in all lateral mini-thoracotomy 
approaches. No chronic pain or related problems were observed.

The presented results suggest less clinical morbidity on posterior approaches due to no management of chest cavity, especially pneumothorax, pneumonia, and neuralgia. In the other hand, more neurological morbidity, especially on central and calcified discs, are present on posterior approach due to cord manipulation to achieve total decompression. These complications are summarized in Table 4. Based on this feature, to avoid major complications, patient clinical status and herniation characteristics are fundamental to choose the best approach to managed thoracic disc herniations.

To reduce clinical and neurological complications, the minimally invasive concept of spinal full endoscopic technique is being studied in thoracic disease. Xiaobing et $a^{21}$ reported a new minimally invasive treatment for thoracic spinal stenosis in 14 patients. Five patients had thoracic disc herniation. A standard transforaminal endoscopic discectomy was performed. 2 patients on thoracic disc herniation had significant neurological improvement on JOA scale. Two patients had dural leakage in this series. More studies are needed to establish the role of spine endoscopy on the management of thoracic disc herniation and if it can improve the security with less morbidity and similar results to standard techniques. 
Table 4. Review Summary - Patient's neurological outcome and complications.

\begin{tabular}{|c|c|c|c|c|c|c|c|c|}
\hline \multirow[b]{2}{*}{ Article - Year } & \multicolumn{4}{|c|}{ Posterior } & \multicolumn{4}{|c|}{ Anterior } \\
\hline & $\mathrm{N}$ & Complications & $\begin{array}{l}\text { Poor } \\
\text { Outcome }\end{array}$ & $\begin{array}{l}\text { Good } \\
\text { Outcome }\end{array}$ & $\mathrm{N}$ & Complications & $\begin{array}{l}\text { Poor } \\
\text { Outcome }\end{array}$ & $\begin{array}{l}\text { Good } \\
\text { Outcome }\end{array}$ \\
\hline Arts $2013^{19}$ & 44 & $2(5 \%)$ & $24 \%$ & $76 \%$ & 56 & $21(38 \%)$ & $28 \%$ & $72 \%$ \\
\hline Ayhan $2010^{16}$ & $x$ & $x$ & $x$ & $x$ & 27 & $6(22 \%)$ & $2(8 \%)$ & $25(92 \%)$ \\
\hline Chi $2008^{8}$ & 11 & Not cited & Zero & $100 \%$ & $x$ & $x$ & $x$ & $x$ \\
\hline Daher $2016^{11}$ & 13 & $4(30 \%)$ & & $100 \%$ & $\mathrm{x}$ & $\mathrm{x}$ & $x$ & $\mathrm{x}$ \\
\hline Khoo 20119 & 13 & $4(30 \%)$ & & $100 \%$ & $\mathrm{x}$ & $x$ & $\mathrm{x}$ & $\mathrm{x}$ \\
\hline Moran $2012^{17}$ & $x$ & $x$ & $x$ & $x$ & 17 & $4(30 \%)$ & $1(8 \%)$ & $12(92 \%)$ \\
\hline Nacar $2013^{14}$ & $\mathrm{x}$ & $\mathrm{x}$ & $\mathrm{x}$ & $x$ & 33 & $6(18.1 \%)$ & $x$ & $100 \%$ \\
\hline Oltulu $2019^{13}$ & 18 & $9(50 \%)$ & $7(14 \%)$ & $\begin{array}{c}42 \\
(85.7 \%)\end{array}$ & 68 & $22(32 \%)$ & $6(42 \%)$ & $8(57.1 \%)$ \\
\hline Uribe $2012^{15}$ & $\mathrm{x}$ & $\mathrm{x}$ & $\mathrm{x}$ & $\mathrm{x}$ & 60 & $4(6,7 \%)$ & $7(16 \%)$ & $35(83.3 \%)$ \\
\hline $\begin{array}{l}\text { Sivakumaran } \\
2018^{12}\end{array}$ & 24 & Zero & $x$ & $100 \%$ & $x$ & $x$ & $x$ & $x$ \\
\hline Regev $2012^{10}$ & 12 & Zero & $x$ & $100 \%$ & $x$ & $x$ & $x$ & $x$ \\
\hline Zhao $2013^{18}$ & $\mathrm{X}$ & $\mathrm{X}$ & $\mathrm{X}$ & $\mathrm{x}$ & 15 & $2(13 \%)$ & $x$ & $100 \%$ \\
\hline Russo $2012^{20}$ & $x$ & $\mathrm{x}$ & $x$ & $\mathrm{x}$ & 7 & $1(14 \%)$ & $x$ & $100 \%$ \\
\hline \multicolumn{9}{|c|}{$\begin{array}{l}\text { *Good outcome was considered to be equal or better neurological status based on Frankel scale (improvement in } \\
\text { pain/radiculopathy was not considered). }\end{array}$} \\
\hline \multicolumn{9}{|c|}{ **Major complications are complications which increase hospitalization time } \\
\hline
\end{tabular}




\section{CONCLUSION}

The treatment of thoracic disc herniation continues to be a challenge for surgeons due to the high risk of neurological damage during the surgery.

There are a great number of approaches described none of them considered the "gold standard", and we think that the best approach depends on each personal case.

The proposed protocol was useful in the decisionmaking process of thoracic disc herniations approaches. According to it we consider the median position and a totally calcified herniation an indication for the anterior approach.

Classifying patients according to their surgical risk and the anatomical peculiarities of the disc herniation allow the surgeon to choose the most suitable approach for each patient, minimizing morbidity and mortality and allowing achieving a complete resection.

Limitations: We presented a very small group of patients and we were not able to assemble statistical measures due to our small cohort.

\section{REFERENCES}

1. Williams MP, Cherryman GR, Husband JE. Significance of thoracic disc herniation demonstrated by MR imaging. J Comput Assist Tomogr 1989;13:211-4. http://doi.org/10.1097/00004728-198903000-00004 2.Ross JS, Perez-Reyes N, Masaryk TJ, BohIman H, Modic MT. Thoracic disk herniation: MR imaging. Radiology 1987;165:511-5.

http://doi.org/10.1148/radiology.165.2.3659375

3.Yoshihara H. Surgical treatment for thoracic disc herniation: an update. Spine 2014;39:E406-12.

http://doi.org/10.1097/BRS.0000000000000171

4. Arseni C, Nash F. Thoracic intervertebral disc protrusion: a clinical study. J Neurosurg 1960;17:418-30.

http://doi.org/10.3171/jns.1960.17.3.0418 
5. Patterson RH Jr, Arbit E. A surgical approach through the pedicle to protruded thoracic discs. J Neurosurg 1978;48:768-72.

http://doi.org/10.3171/jns.1978.48.5.0768

6.Stillerman CB, Chen TC, Day JD, Couldwell WT, Weiss MH. The transfacet pedicle-sparing approach for thoracic disc removal: cadaveric morphometric analysis and preliminary clinical experience. J Neurosurg 1995;83:971-6.

http://doi.org/10.3171/jns.1995.83.6.0971

7.Iunes EA, Onishi FJ, Benites VDM, Yunes RM, Elias AJR, Cavalheiro S. Thoracic disc herniation: Case series and protocol for surgical approaches. Coluna/Columna 2016;15:299302. https://doi.org/10.1590/s1808-185120161504086526

8.Chi JH, Dhall SS, Kanter AS, Mummaneni PV. The Mini-Open transpedicular thoracic discectomy: surgical technique and assessment. Neurosurg Focus 2008;25:E5.

http://doi.org/10.3171/FOC/2008/25/8/E5

9. Khoo LT, Smith ZA, Asgarzadie F, Barlas Y, Armin SS, Tashjian V, et al. Minimally invasive extracavitary approach for thoracic discectomy and interbody fusion: 1-year clinical and radiographic outcomes in 13 patients compared with a cohort of traditional anterior transthoracic approaches. J Neurosurg Spine 2011;14:250-60.

http://doi.org/10.3171/2010.10.SPINE09456

10.Regev GJ, Salame K, Behrbalk E, Keynan O, Lidar Z. Minimally invasive transforaminal, thoracic microscopic discectomy: technical report and preliminary results and complications. Spine J 2012;12:570-6. http://doi.org/10.1016/j.spinee.2012.07.001

11.Tavares Daher M, Felisbino Júnior $P$, Passáglia Esperidião $A$, Ribeiro Araújo BC, Passos Cardoso AL, Pimenta Júnior WE, et al. Thoracic disc herniation: Surgical decompression by posterior approach a la carte. Coluna/Columna 2016;15:213-8. https://doi.org/10.1590/S1808185120161503157849

12.Sivakumaran R, Uschold TD, Brown MT, Patel NR. Transfacet and Transpedicular Posterior Approaches to Thoracic Disc Herniations: Consecutive Case Series of 24 Patients. World Neurosurg 2018;120:e921-31. http://doi.org/10.1016/j.wneu.2018.08.191

13. Oltulu I, Cil H, Berven S, Chou D, Clark A, Ulu MO, et al. Surgical Management of Thoracic Disc Herniation: Anterior vs Posterior Approach. Turk Neurosurg 2019;29:584-93.

http://doi.org/10.5137/1019-5149.JTN.24969-18.2

14. Nacar OA, Ulu MO, Pekmezci M, Deviren V. Surgical treatment of thoracic disc disease via minimally invasive lateral transthoracic trans/retropleural approach: analysis of 33 patients. Neurosurg Rev 2013;36:455-65. http://doi.org/10.1007/s10143-013-0461-2

15.Smith R, Christian G, Oliveira L, Marchi L, Deviren V. Minimally invasive lateral approach for symptomatic thoracic disc herniation: initial multicenter clinical experience. J Neurosurg Spine 2012;16:26479. http://doi.org/10.3171/2011.10.SPINE11291

16. Ayhan S, Nelson C, Gok B, Petteys RJ, Wolinsky JP, Witham TF, et al. Transthoracic surgical treatment for centrally located thoracic disc 
herniations presenting with myelopathy: a 5-year institutional experience. J Spinal Disord Tech 2010;23:79-88. http://doi.org/10.1097/BSD.0b013e318198cd4d

17. Moran C, Ali Z, McEvoy L, Bolger C. Mini-open retropleural transthoracic approach for the treatment of giant thoracic disc herniation. Spine 2012;37:E1079-84.

http://doi.org/10.1097/BRS.0b013e3182574657

18.Zhao Y, Wang Y, Xiao S, Zhang Y, Liu Z, Liu B. Transthoracic approach for the treatment of calcified giant herniated thoracic discs. Eur Spine J 2013;22:2466-73. http://doi.org/10.1007/s00586-013$\underline{2775-8}$

19.Arts MP, Bartels RH. Anterior or posterior approach of thoracic disc herniation? A comparative cohort of mini-transthoracic versus transpedicular discectomies. Spine J 2014;14:1654-62.

http://doi.org/10.1016/j.spinee.2013.09.053

20.Russo A, Balamurali G, Nowicki R, Boszczyk BM. Anterior thoracic foraminotomy through mini-thoracotomy for the treatment of giant thoracic disc herniations. Eur Spine J 2012;21(Suppl 2):S212-20. http://doi.org/10.1007/s00586-012-2263-6

21. Xiaobing Z, Xingchen L, Honggang Z, Xiaoqiang C, Qidong Y, Haijun $M$, et al. "U" route transforaminal percutaneous endoscopic thoracic discectomy as a new treatment for thoracic spinal stenosis. Int Orthop 2019;43:825-32. http://doi.org/10.1007/s00264-018-4145-y 